\title{
Predictability of stream flow and rainfall based on ENSO for water resources management in Sri Lanka
}

\author{
Janaki Chandimala ${ }^{a}$, Lareef Zubair ${ }^{\mathrm{b}, *}$ \\ ${ }^{a}$ Foundation for Environment, Climate and Technology, Digana Village, Rajawella, Sri Lanka \\ b International Research Institute for Climate and Society, The Earth Observatory at Columbia \\ University, P.O. Box 1000 (61 Route 9W), Palisades, NY 10964, USA
}

Received 4 June 2005; received in revised form 13 November 2006; accepted 27 November 2006

KEYWORDS
El Niño-southern
oscillation;
Seasonal climate
predictions;
Streamflow variability;
Monsoon;
Sri Lanka

\footnotetext{
* Corresponding author. Tel.: +1 845680 4424; fax: +1 845680 4864.
}

E-mail address: lareef@iri.columbia.edu (L. Zubair). cross-validated mode.
Summary We investigate the viability of using El Niño-Southern Oscillation (ENSO) and sea surface temperature (SST) data to predict seasonal streamflow for one of the major rivers in Sri Lanka, the Kelani, using correlation analysis, contingency tables, and principal component analysis. The agricultural seasons in Sri Lanka are Yala (April-September) and Maha (October-March). The correlation between the Kelani River streamflow during Yala and ENSO indices $(r=-0.41)$ is significant at $99 \%$ level. In addition, the Kelani streamflow during Yala has a correlation with the Central Indian Ocean SST $(r=-0.40)$ that is also significant at the $99 \%$ level. The first principal component of the Indo-Pacific Ocean SST is reminiscent of the SST associated with the ENSO mode. A prediction scheme based on this mode for the streamflow during Yala has a skill characterized by a correlation of 0.5 in a

The prediction of streamflow during Maha is best carried out separately for the two halves of the season. During the El Niño phase, the rainfall during Maha is enhanced during the first half of the season (October-December) and diminished in the second half (January-February). Rainfall rather than streamflow has a better relationship with ENSO from October to December. During the second half of the Maha season, rainfall declines with both warm and cold ENSO phases and any prediction scheme has to take into account this non-linear relationship. Overall, useful skill for seasonal streamflow predictions has been demonstrated for the Yala season and skill for seasonal rainfall predictions for the first and second half of the Maha season has been elucidated.

(c) 2006 Elsevier B.V. All rights reserved.

\section{Introduction}

The principal global climate teleconnection of El NiñoSouthern Oscillation (ENSO) affects hydrology in much of 
the tropics through its impacts on the variables such as rainfall, temperature and evaporation (Dettingter and Diaz, 2000). These ENSO influences extend to Sri Lanka rainfall (Rasmusson and Carpenter, 1983; Ropelewski and Halpert, 1987). Sensitivity of streamflow to ENSO has been investigated for a number of rivers in all continents and several reviews are available (Kiem and Franks, 2001; Dettinger et al., 2000 and Chiew and McMahon, 2002). In the South Asian region, relationships have been identified between streamflow and ENSO in India and Bangladesh (Chowdhury and Ward, 2004; Whitaker et al., 2001), Nepal (Shrestha and Kostaschuk, 2005) and Sri Lanka (Zubair, 2003b,c).

Studies on the ENSO impacts in Sri Lanka are important as it presents information about the low-latitude region of South Asia which experiences rainfall throughout the year. The phases of the ENSO phenomena associated with warmer and colder than normal sea surface in the equatorial Central and Eastern Pacific Ocean are referred to as El Niño and La Niña, respectively. The rainfall of Sri Lanka and India is diminished during El Niño episodes in the boreal summer due to large-scale subsidence over the Central Indian Ocean region (Kumar et al., 1999) and enhanced from October to December (Rasmusson and Carpenter, 1983; Ropelewski and Jones, 1987; Suppiah, 1996, 1997).

The climate of Sri Lanka is modulated during ENSO extremes due to the alteration in intensity and location of the large-scale equatorial circulation system associated with it referred to as the Walker cell (Allen et al., 1996). From April to September, rainfall over Sri Lanka is relatively lower during El Niño similar to anomaly patterns over the Indian peninsula. During the October-December season, the eastward displacement of the Walker cell in the Indian Ocean is such that Sri Lanka receives increased rainfall anomalies (Zubair et al., 2003a, Zubair and Ropelewski, 2006). This relationship is important as the October-December period accounts for a third of the annual rainfall.

Here we investigate the possibility of using ENSO for the management of water resources in the Kelani River in Sri Lanka (Fig. 1). The Kelani is the second largest river in Sri Lanka by volume of discharge although it is only the sixth largest in watershed size (Arumugam, 1969). The highest annual rainfall in Sri Lanka is observed in the upper reaches of the Kelani catchment and the areal average annual rainfall is $3880 \mathrm{~mm}$. Two reservoirs and five hydropower plants have been built to utilize the flow for hydropower generation. These power plants generate $38 \%$ of the total hydropower production in Sri Lanka (Siyambalapitiya and Samarasinghe, 1993). The Kelani feeds the municipal and industrial water supply to 2.2 million people in Colombo, from reservoirs on tributaries that join the main Kelani River below Glencourse gorges (Fig. 2). The lowland areas downstream of Glencourse gorges are frequently subjected to flooding. The other major rivers in Sri Lanka, Mahaweli, Kalu and Walawe, share boundaries with the Kelani in the upper catchment and interpretations from this work is likely to have some bearing on the other rivers.

The agricultural seasons in Sri Lanka last from April to September (Yala) and October to March (Maha) (Zubair, 2002). Choices are made at the start of the season as to what extent of land is to be cultivated, and whether more irrigation intensive rice crops should be cultivated. Hence

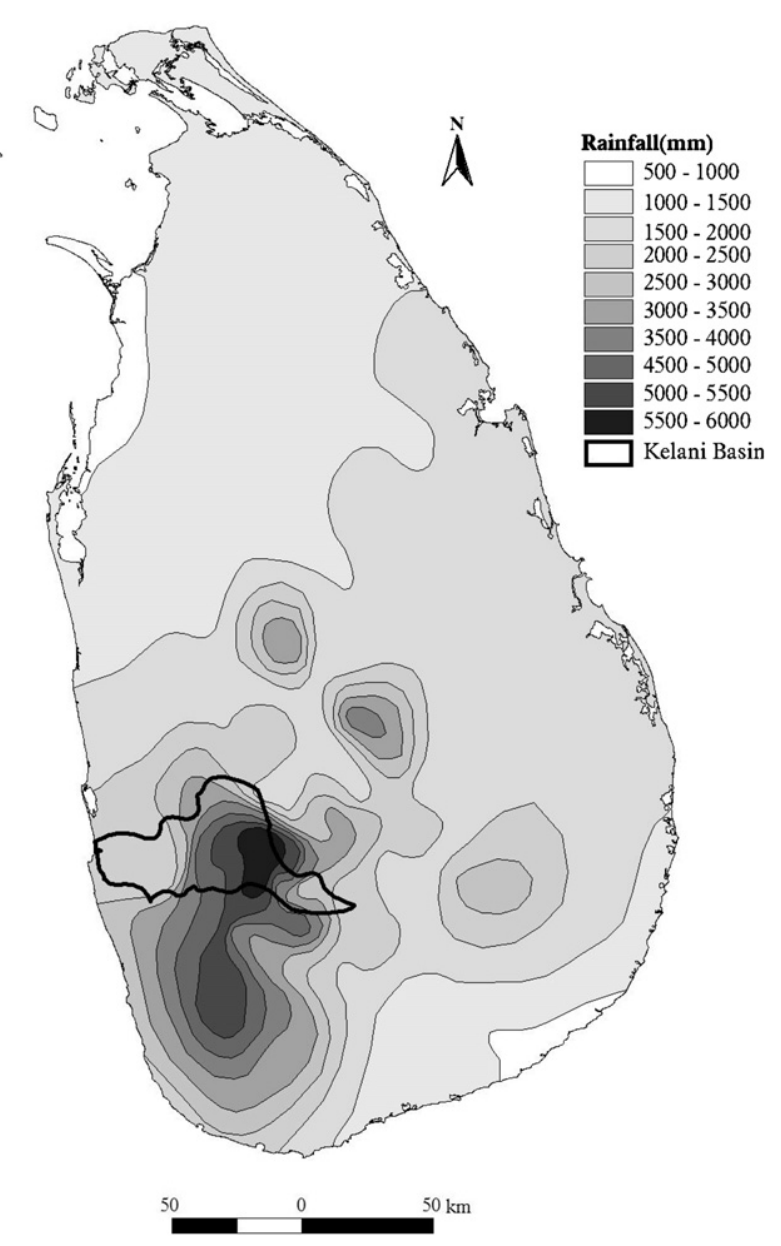

Figure 1 The Kelani basin is outlined within the map of Sri Lanka. Sri Lanka is located between 79.9 and $81.9^{\circ} \mathrm{E}$ longitude and between 5.9 and $9.9^{\circ} \mathrm{N}$ latitude. The shading shows the annual rainfall climatology computed from 174 rainfall stations in the island for the period from 1960 to 1990.

rainfall and streamflow predictions are needed at the start of these seasons. Previously, the ENSO influence for the January-September streamflow in Sri Lanka was reported (Zubair, 2003b,c). However, this period does not match with the seasons of interest to water managers and agricultural managers who take seasonal planning decisions in April and September for the April-September and October-March cultivation seasons. Here we seek to establish the relationships between ENSO and streamflow or rainfall for Yala and Maha, and to assess the potential for ENSO based predictions for water management.

\section{Data and methods}

Monthly sea surface temperatures, rainfall and streamflow data for 1950-2000 were used.

\section{SST and ENSO data}

The monthly sea surface temperature (SST) (Kaplan et al., 1998) is available at http://iridl.ldeo.columbia.edu/ SOURCES/.KAPLAN/.EXTENDED/.v2/.ssta/ from 1856. The 

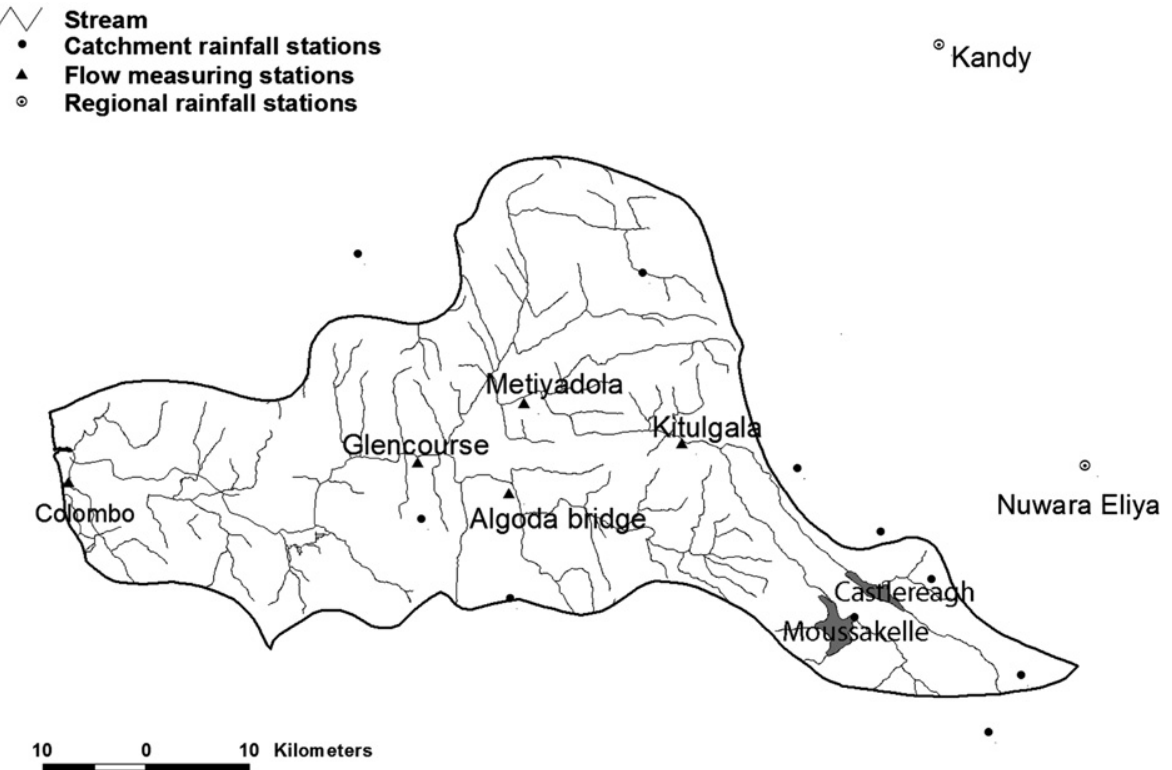

$\odot$ Ratnapura

Figure 2 The Kelani river network is shown along with two reservoirs (Castlereagh and Maussakelle) in its highest reaches. The Sri Lanka Department of Meteorology rainfall observation stations are shown as a bull's eye and the other rainfall stations used in the analysis are shown as solid circles. The river discharge stations (Kitulagala, Algoda Bridge, Metiyadola, Glencourse and Colombo) referred to in the text are shown as solid triangles.

SST in various regions of the equatorial Eastern Pacific Ocean regions (indicated in brackets) are averaged for each ENSO index: NINO12 $\left(80^{\circ} \mathrm{W}-90^{\circ} \mathrm{W}, 10^{\circ} \mathrm{S}-\right.$ Equator $)$, NINO3 $\left(120^{\circ} \mathrm{W}-150^{\circ} \mathrm{W}, 5^{\circ} \mathrm{S}-5^{\circ} \mathrm{N}\right)$, NINO3.4 $\left(120^{\circ} \mathrm{W}-170^{\circ} \mathrm{W}, 5^{\circ} \mathrm{S}-\right.$ $\left.5^{\circ} \mathrm{N}\right)$ and NINO4 $\left(150^{\circ} \mathrm{W}-180^{\circ} \mathrm{W}, 5^{\circ} \mathrm{S}-5^{\circ} \mathrm{N}\right)$ (Allen et al., 1996).

The three ENSO phases of El Niño, La Niña and Neutral are identified as seasons when the NINO3.4 was above $0.4^{\circ} \mathrm{C}$, below $-0.4{ }^{\circ} \mathrm{C}$ or in between these two limits, respectively (Trenberth, 1997). The atmospheric pressure based index of "Southern Oscillation Index" (SOI) was obtained following Ropelewski and Jones (1987).

\section{Rainfall data}

The Kelani catchment lies within a climatically homogeneous Western hill slopes region as identified by Puvaneswaran and Smithson (1993). There are 16 stations within or close to the Kelani catchment at government hospitals, railway stations and tea estates (Zubair, 2004). The rain gauges are provided by the Department of Meteorology, and the Department personnel inspect these gauges, archive the data and undertake quality control of it. We have undertaken further quality tests for this data - identifications of outliers, cross checks for extreme values, checks for drifts in the data and cross-correlation analysis. Based on these analyses we decided to use only 10 of these stations that had good coverage of the basin (Fig. 2). A monthly catchment rainfall index was constructed for Glencourse by areally averaging rainfall observations of these 10 stations.

We compared the results with monthly rainfall observations at three Sri Lanka Department of Meteorology stations that are distributed in the wider Western hill slopes region (Kandy $\left(7^{\circ} 20^{\prime} \mathrm{N}, 80^{\circ} 38^{\prime} \mathrm{E}, 477 \mathrm{~m}\right.$ above sea level (a.s.l.)), Nuwara Eliya $\left(6^{\circ} 58^{\prime} \mathrm{N}, 80^{\circ} 46^{\prime} \mathrm{E}, 1895 \mathrm{~m}\right.$ a.s.l), and Ratnapura $\left(6^{\circ} 40^{\prime} \mathrm{N}, 80^{\circ} 25^{\prime} \mathrm{E}, 34 \mathrm{~m}\right.$ a.s.l)) (Fig. 2). A representative rainfall index for the Western Hill slopes (regional rainfall index) was constructed by averaging the rainfall of these stations. The catchment rainfall has a similar seasonality as the regional rainfall (Fig. 3a). The catchment rainfall is fractionally greater than the regional rainfall, as it is more compactly located in a region with the highest rainfall over Sri Lanka from March to November.

\section{Streamflow data}

The Kelani river originates in the central hills at Kirigalpotha mountain range $(2420 \mathrm{~m}$ a.s.l.) and discharges to the sea $144 \mathrm{~km}$ downstream at Colombo. The upper reaches of the basin is covered with tea plantations and forested lands whereas the middle and lower reaches have rubber and rice cultivation. The soil type in the basin is typically red-yellow podzolic soil with soft and hard laterite (Panabokke, 1996). Streamflow records for the Kelani are available at 15 streamflow measuring stations from the Sri Lanka Department of Irrigation. The station that has the longest record is at Glencourse $\left(6^{\circ} 58^{\prime} \mathrm{N}, 80^{\circ} 10^{\prime} \mathrm{E}, 32 \mathrm{~m}\right.$ a.s.l., $1463 \mathrm{~km}^{2}$ catchment) where the Kelani descends to the lowlands. We obtained records from 1948 to 1999 . The data at Glencourse was checked for consistency with neighboring gauge stations. On average the annual streamflow at Metiyadola, Algoda Bridge and Kitulgala (Fig. 2) accounts for approximately $40 \%, 20 \%$, and $26 \%$ of the annual streamflow at Glencourse (4500 MCM).

We have compared the streamflow at Glencourse based on upstream and downstream stations, and found the 

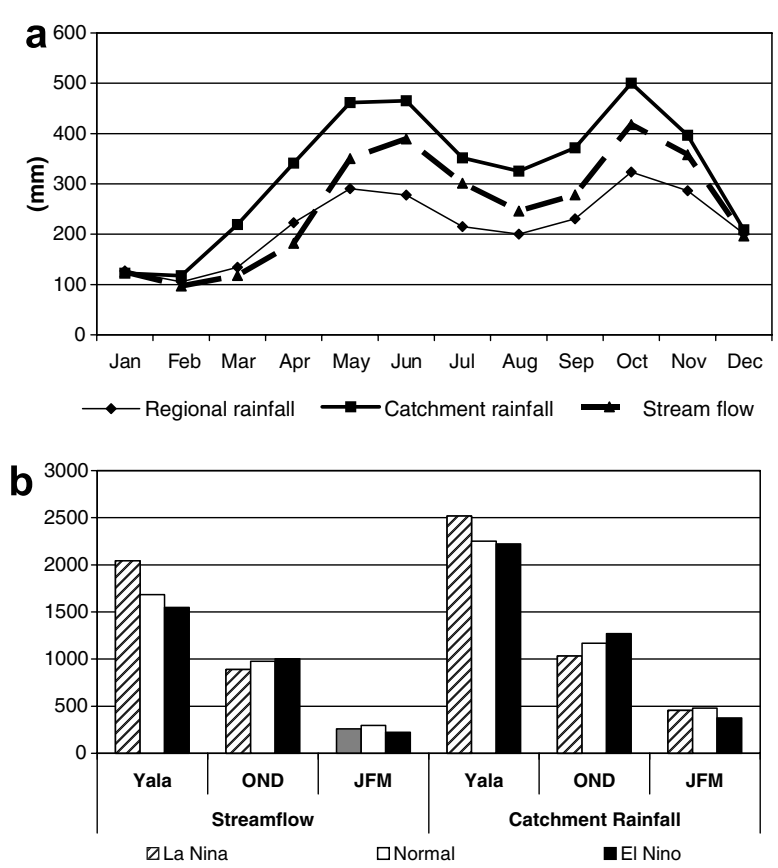

Figure 3 (a) Mean monthly streamflow and catchment rainfall at Glencourse and the regional rainfall for 1950-2000. The streamflow hydrograph is in units of volume per unit area of the catchment in $\mathrm{mm}$. Area of the catchment at Glencourse is $1463 \mathrm{~km}^{2}$. (b) The seasonal average of streamflow and rainfall during El Niño, Neutral and La Niña phases for Yala, early Maha and late Maha. The average percent rise of streamflow (rainfall) during El Niño phase when compared with the Neutral phase is $-8(-1), 3(9)$ and $-25(-22)$ for Yala, early Maha and late Maha, respectively: the percent rise during the La Niña phase when compared with the Neutral phase is 21(12), $-9(-12)$ and $-13(-5)$ for Yala, early Maha and late Maha, respectively.

Glencourse data to be reasonably consistent with other stations. There were some inaccuracy with high-flows and when these were particularly egregious we obtained the best estimate considering the neighbouring stations and rainfall. For example, the August 1947 flood was underestimated. The number of data points that were adjusted were less than $5 \%$ of the record.

Two reservoirs have been constructed in the higher reaches of the Kelani starting in 1953 as storage for hydroelectricity generation stations. These reservoirs have a small storage capacity of 169 million cubic meters (MCM) and a drainage area of 236 square kilometers. The impacts of reservoir management on streamflow at Glencourse may be reasonably overlooked for this analysis given that the reservoirs affect only $10 \%$ of the Glencourse catchment. The findings reported here were verified with a shorter record of the inflow to the Moussakelle reservoir (Fig. 2).

\section{Global circulation}

Global circulation fields at $200 \mathrm{hPa}$ pressure level were obtained from the NCEP-NCAR reanalysis at monthly frequency starting from 1948 (Kistler et al., 2001).

\section{Methods}

\section{Correlation analysis}

The Pearson product moment coefficient of linear correlation was applied to identify the streamflow or rainfall relationships with ENSO indices (Wilks, 1995). The technique of partial correlations was used to find the relative significance of additional variables by removing the correlation of ENSO index with it in a statistical sense. The partial correlation (Fisher, 1925) between $Y$ and $X$ controlling for $W$ may be obtained as

$r_{Y X} \cdot w=\frac{r_{X Y}-r_{X W} r_{Y W}}{\sqrt{\left(1-r_{X W}^{2}\right)\left(1-r_{Y W}^{2}\right)}}$

\section{Contingency tables}

Contingency tables are constructed to identify the influence of ENSO on a variable such as streamflow based on historical data (Wilks, 1995). The ENSO phases are identified based on the prevalent value for an ENSO index in categories as El Niño, Neutral and La Niña. Similarly, the streamflow are segregated in terciles representing "below-normal", "near-normal" and "above-normal" flow. The occurrences of ENSO phases and streamflow conditions in different ENSO/streamflow tercile combinations are tabulated providing a summary of the association between ENSO phases and streamflow terciles.

\section{Heidke skill scores}

The Heidke skill score (HSS) is a measure of forecast skill that is widely used when the forecasts and corresponding observations are expressed in categories as below normal, near-normal and above-normal (Wilks, 1995). The score is based on the number of forecasts where the category with the largest forecasted probability turned out to be correct. The skill is given by HSS $=100(C-E) /(N-E)$, where $C$ is the number of correct forecasts, $E$ is the number of correct forecasts expected by chance and $N$ is the total number of forecasts. In the computation of the Heidke score, we used the observed occurrences of rainfall and ENSO episodes to determine the probabilities expected by chance. An all-correct forecast results in a score of 100 , while a forecast with as many correct as expected by chance scores 0 . The typical skill of seasonal predictions which is obtained operationally based on Global Climate Models over land is of the order of 10 (Mason et al., 1999). While the Heidke skill score has its drawbacks, it serves as a quick but approximate index of predictability.

\section{Results}

\section{Mean annual cycle}

The rainfall climatology of Sri Lanka has a bimodal distribution (Fig. 3a) with peaks around May and November due to the rain associated with the passage of the Inter-Tropical convergence zone over Sri Lanka (Bamford, 1922). In addition, winter monsoonal influences and cyclonic storms from 
the Bay of Bengal contribute to high rainfall from October to December (Zubair and Ropelewski, 2006). The Western hill slopes receive considerable orographic rainfall from May to September when strong Westerly winds prevail. The Kelani catchment is located on one of the steepest westward facing hill slopes.

As there is year round rainfall and streamflow in this catchment, there is no clear-cut means of demarcating the seasons. Most useful for water resources management is the traditional demarcation of seasons based on the agricultural seasons (Maha from October to March and Yala from April to September). Decisions regarding seasonal water allocations are made at the start of the seasons.

\section{Relationships with large scale circulation}

During El Niño episodes, the anomalous warming in the tropical Western Pacific Ocean leads anomalous convection over the Eastern tropical Pacific Ocean warm pool setting up an anomalous zonal large scale circulation referred to as the Walker circulation. The $200 \mathrm{hPa}$ velocity potential anomaly fields is a good proxy for representing the Walker circulation (Kumar et al., 1999). Global circulation fields are available from 1948 onwards from the NCEP-NCAR analysis. We constructed the composite of the April-September $200 \mathrm{hPa}$ velocity potential anomaly fields for the El Niño episodes from 1948 to 2000 (Fig. 4a). The velocity potential anomaly field during warm episodes shows that there is enhanced subsidence over South and South-East Asia and parts of the Indian Ocean. Subsidence over the Indian Ocean including Sri Lanka leads to reduction in cloud formation and rainfall consistent with the observed reduction in rainfall during the Yala.
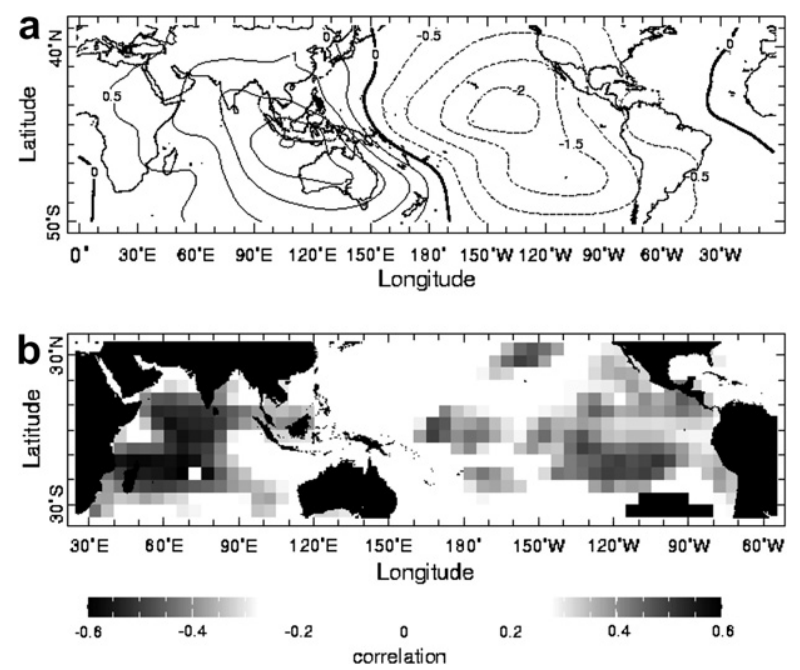

Figure 4 (a) Composites of the April-September velocity potential anomalies $\left(\chi \times 10^{-6} \mathrm{~m}^{2} \mathrm{~s}^{-1}\right)$ at $200 \mathrm{hPa}$ for El Niño seasons are shown. The El Niño seasons were 1963, 1965, 1968, 1969, 1972, 1976, 1977, 1982, 1986, 1987, 1991, 1994, 1997 and 2002. (b) The correlation of April-September sea surface temperatures with simultaneous Glencourse streamflow for 1975-2000. Correlations that are significant at 99\%, 95\% and $90 \%$ correspond to $r=0.44,0.38$ and $0.32(n=26)$.
We also constructed the simultaneous correlation between the April-September streamflow and the Indo-Pacific SST (Fig. 4b): it shows a high correlation with the eastern equatorial Pacific Ocean and the Central Indian Ocean with a spatial pattern reminiscent of ENSO providing further evidence for linkage between ENSO and the streamflow during Yala.

During the October-December period, the zone of subsidence over the Indian Ocean and East Africa is shifted northeastwards and as a result convection over Sri Lanka and Southern India is enhanced during El Niño episodes (Zubair and Ropelewski, 2006).

\section{ENSO-streamflow relationships}

\section{Yala (April-September)}

The Kelani streamflow during Yala declines during warm ENSO episodes and is enhanced during cold ENSO episode on average (Fig. 5a). The average streamflow during Yala in the La Niña phase is $32 \%$ higher than that in the El Niño phase (Fig. 3b). The seasonal streamflow during Yala has a negative correlation with NINO indices that is significant at the $95 \%$ confidence limit (Table 1 ). The above relationships hold, albeit with lower levels of statistical significance, for the streamflow at the headstream above the Maussakelle reservoir inflow as well.
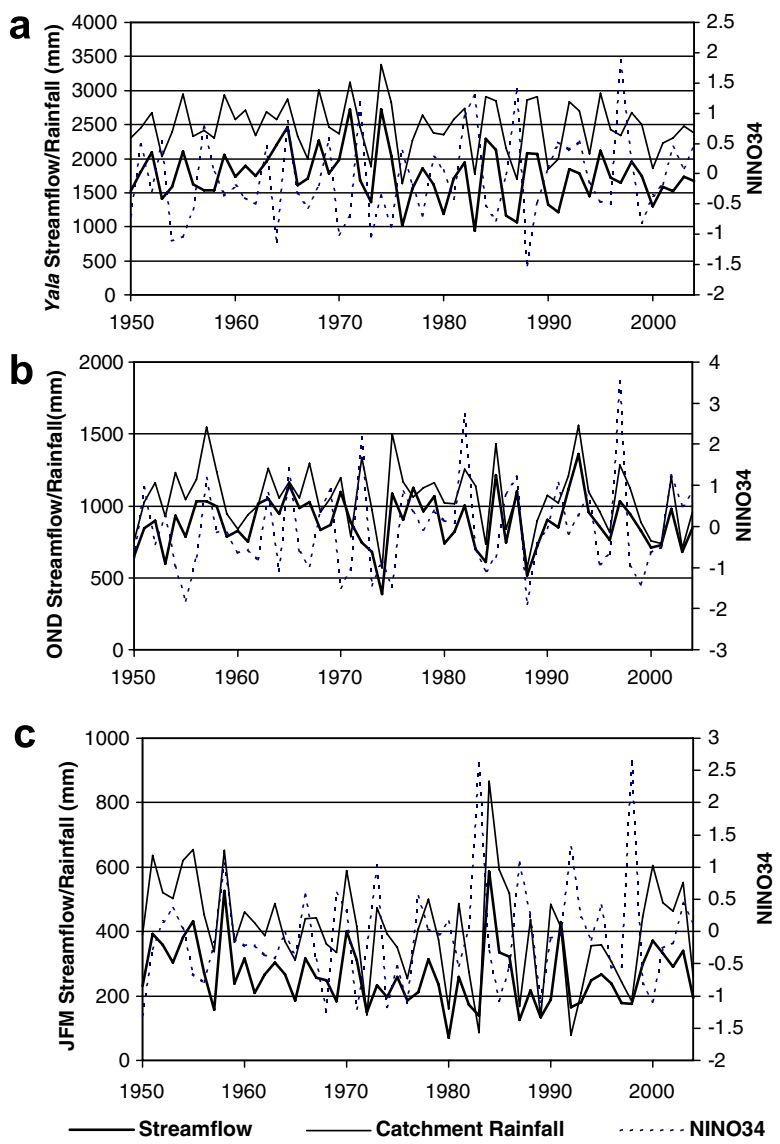

Figure 5 The time series of aggregate streamflow and aggregate catchment rainfall for Glencourse and the concurrent average NINO3.4 index are shown for (a) Yala, (b) Early Maha and (c) Late Maha. 
Table 1 Quarterly characteristics of Kelani streamflow at Glencourse based on records from 1950 to 2000

\begin{tabular}{lllllll}
\hline Characteristic & \multicolumn{2}{l}{ Season } & & & & \\
\cline { 2 - 7 } & JFM & AMJ & JAS & OND & Annual total & Yala (AMJJAS) \\
\hline Mean discharge (mm) & 268 & 868 & 854 & 942 & 2931 & 1722 \\
Standard deviation (mm) & 111 & 316 & 329 & 271 & 665 & 507 \\
Correlation w/NINO12 & -0.32 & -0.25 & -0.35 & -0.03 & -0.40 & -0.40 \\
Correlation w/NINO3 & -0.10 & -0.25 & -0.36 & 0.11 & -0.47 & -0.42 \\
Correlation w/NINO3.4 & -0.10 & -0.24 & -0.36 & 0.17 & -0.41 & -0.41 \\
Correlation w/NINO4 & -0.11 & -0.19 & -0.46 & -0.16 & -0.42 & -0.46 \\
Correlation w/SOI & 0.11 & 0.05 & 0.47 & 0.21 & 0.39 & 0.37 \\
\hline
\end{tabular}

The correlations of streamflow with ENSO indices for the same period are also shown. Correlations that are significant at $99 \%, 95 \%$ and $90 \%$ corresponding to $r=0.35,0.27$ and $0.23(n=51)$ are shown in bold, bold italics and italics.

A relationship associating El Niño with Above-Normal, Neutral with near-normal and La Niña with below-normal streamflow is verified in 24 occasions out of 51 Yala seasons (Table 3a) resulting in a Heidke Skill score of 21.

\section{Maha (October-March)}

The influence of ENSO on the Maha rainfall changes after the first half of this season. During the El Niño phase there is enhanced convection over Sri Lanka from October to December (Zubair and Ropelewski, 2006) but in the months that follow there is enhanced subsidence (Zubair and Chandimala, 2006). Therefore, to obtain the most predictability based on ENSO, we need to consider the OctoberDecember and January-March periods separately.

\section{Early Maha (October-December)}

The streamflow during this season (Fig. 5b) show modest drops in the second half of the record. The OctoberDecember rainfall increases during the El Niño and declines during La Niña. This relationship is clearer cut for rainfall than streamflow. During the first half of the Maha season, the streamflow during the El Niño phase is $11 \%$ greater than that during the La Niña phase. Simultaneous correlation of October-December (Early Maha) streamflow with ENSO indices are at insignificant levels (Table 1) with weak signs of an El Niño-Wet and La Niña-Dry association (Table 3b), the Heidke skill score is only 9.

\section{Late Maha (January-March)}

The January-March streamflow (Fig. 5c) declines on average during both ENSO phases (Fig. 3b). The streamflow during both El Niño and La Niña phases are less $(-25 \%$ and $-13 \%$, respectively) than that during the Neutral phase.

The contingency table based on NINO3.4 (Table 3c) shows that streamflow values tend to an El Niño-Dry and La Niña-Wet relationship with NINO3.4 resulting in a Heidke skill score of 12 . The January-March (Late Maha) streamflow has a significant relationship with NINO12 in the far Eastern Pacific Ocean $(r=-0.41)$.

\section{ENSO-rainfall relationships}

\section{Yala (April-September)}

The Yala rainfall during the La Niña phase is $13 \%$ higher than that during the El Niño on average (Fig. 3b). The ENSO-rainfall correlation during the Yala season (Table 2 ) is markedly less than that for the ENSO-streamflow correlation (Table 1 ).

Predictions of rainfall associating El Niño with AboveNormal, Neutral with near-normal and La Niña with belownormal results is verified in 23 occasions out of 51 Yala seasons (Table $3 a$ ) resulting in a Heidke Skill score of 18. Overall, the analysis shows that ENSO based predictions of Yala rainfall has some skill which is less than that obtained for streamflow predictions.

Table 2 Quarterly characteristics of rainfall in Glencourse catchment based on average rainfall records for 10 stations in the catchment from 1950 to 2000

\begin{tabular}{lllllll}
\hline Characteristic & \multicolumn{2}{l}{ Season } & & & & \\
\cline { 2 - 7 } & JFM & AMJ & JAS & OND & Annual total & Yala (AMJJAS) \\
\hline Mean rainfall (mm) & 448 & 1288 & 1060 & 1130 & 3926 & 2348 \\
Standard deviation (mm) & 167 & 314 & 268 & 271 & 538 & 413 \\
Correlation with NINO12 & -0.41 & -0.14 & -0.11 & 0.33 & -0.19 & -0.17 \\
Correlation with NINO3 & -0.19 & -0.25 & -0.17 & 0.46 & -0.17 & -0.23 \\
Correlation with NINO3.4 & -0.16 & -0.21 & -0.26 & $\mathbf{0 . 4 4}$ & -0.10 & -0.25 \\
Correlation with NINO4 & -0.11 & -0.19 & -0.41 & $\mathbf{0 . 3 5}$ & -0.12 & $-\mathbf{0 . 3 0}$ \\
Correlation with SOI & 0.22 & 0.08 & $\mathbf{0 . 4 3}$ & $-\mathbf{0 . 3 3}$ & 0.17 & $\mathbf{0 . 3 1}$ \\
\hline
\end{tabular}

The correlations of rainfall with ENSO indices and rainfall for the same period are also shown. Correlations that are significant at $99 \%, 95 \%$ and $90 \%$ corresponding to $r=0.35,0.27$ and $0.23(n=51)$ are shown in bold, bold italics and italics. 
Table 3 Contingency table for the ENSO association with simultaneous streamflow and catchment rainfall (in brackets) at Glencourse between 1950 and 2000 for (a) Yala, (b) early Maha and (c) late Maha

\begin{tabular}{|c|c|c|c|}
\hline & Below-normal & Near-normal & Above-normal \\
\hline \multicolumn{4}{|c|}{ (a) Yala (April-September) } \\
\hline Rainfall (streamflow) & $<1795 \mathrm{~mm}(<2529 \mathrm{~mm})$ & 1795-2212 mm (2529-2814 mm) & $>2212 \mathrm{~mm}(>2814 \mathrm{~mm})$ \\
\hline El Niño $\left(>0.4^{\circ} \mathrm{C}\right)$ & $6(6)$ & $6(6)$ & $3(3)$ \\
\hline Neutral & $7(7)$ & $11(11)$ & $7(7)$ \\
\hline La Niña $\left(<-0.4^{\circ} \mathrm{C}\right)$ & $3(3)$ & $2(1)$ & $6(7)$ \\
\hline \multicolumn{4}{|c|}{ (b) Early Maha (October-December) } \\
\hline Rainfall (streamflow) & $<820 \mathrm{~mm}(<1032 \mathrm{~mm})$ & $820-1015 \mathrm{~mm}(1032-1247 \mathrm{~mm})$ & $>1015 \mathrm{~mm}(>1247 \mathrm{~mm})$ \\
\hline El Niño $\left(>0.4^{\circ} \mathrm{C}\right)$ & $1(2)$ & $7(5)$ & $6(7)$ \\
\hline Neutral & $4(3)$ & $3(6)$ & $5(4)$ \\
\hline La Niña $\left(<-0.4^{\circ} \mathrm{C}\right)$ & $11(11)$ & $8(8)$ & $6(6)$ \\
\hline \multicolumn{4}{|c|}{ (c) Late Maha (January-March) } \\
\hline Rainfall (streamflow) & $<217 \mathrm{~mm}(<187 \mathrm{~mm})$ & $217-304 \mathrm{~mm}(187-427 \mathrm{~mm})$ & $>304 \mathrm{~mm}(>427 \mathrm{~mm})$ \\
\hline El Niño $\left(>0.4^{\circ} \mathrm{C}\right)$ & $6(6)$ & $2(5)$ & $2(3)$ \\
\hline Neutral & $6(3)$ & $7(6)$ & $8(4)$ \\
\hline La Niña $\left(<-0.4^{\circ} \mathrm{C}\right)$ & $4(7)$ & $9(8)$ & $7(10)$ \\
\hline
\end{tabular}

The ENSO phases are defined based on the seasonal average NINO34 values as follows: El Niño (NINO34 >0.4), Neutral $(-0.4>$ NINO34 $>0.4)$ and La Niña $(-0.4>$ NINO34). The rainfall categories are based on terciles and the limits of these terciles are indicated for rainfall with values in brackets for streamflow.

\section{Maha (October-March)}

We consider the first and second half of the season separately.

\section{Early Maha (October-December)}

During the first half of the Maha season, the rainfall during the El Niño phase is $23 \%$ greater than that during the La Niña phase (Fig. 3b). The correlation of ENSO indices with October-December rainfall is more significant (Table 2) than with streamflow (Table 1). The contingency table (Table 3b) shows significant distinction between the El Niño and La Niña phases for the October-December season which is brought out by a Heidke skill score of 18 .

\section{Late Maha (January-March)}

During the second half of the season, the rainfall during both El Niño and La Niña phases are modestly less $(-22 \%$ and $-5 \%$, respectively) than that during the Neutral phase.

Rainfall and ENSO indices are negatively correlated yet, only the NINO12 index is statistically significant at the $95 \%$ level. The Heidke skill score for an ENSO based prediction assuming lower rainfall values for El Niño and La Niña is 15 (Table 3c).

\section{Rainfall and streamflow relationships with Indian Ocean indices}

Regional influences particularly from the Indian Ocean are likely to have a significant influence on the Kelani river basin. Recently, the "Equatorial Indian Ocean Oscillation"' (EQUINOO) (Gadgil et al., 2004) has been found to be useful along with ENSO in explaining the inter-annual variations in the Indian summer monsoon rainfall (May-September). Maity and Nagesh Kumar (2006) presented a Bayesian dynamic model for predicting monthly streamflow during the summer in India.

Gadgil et al. (2004) have suggested the use of the Equatorial Zonal Wind (EQWIN) as an index of the EQUINOO phenomenon. The streamflow and rainfall in the Kelani catchment show only a modest correlation with the EQWIN (Table 4). Further analysis using the sum of the indices (EQWIN + NINO3.4) following Gadgil et al. (2004) did not yield

Table 4 The correlation of the Yala (April-September) rainfall (RF) and streamflow (SF) with the NINO34, NDMI, EQWIN, EQWIN + NINO34 and CEIO

\begin{tabular}{|c|c|c|c|c|c|c|}
\hline & \multicolumn{2}{|c|}{$1946-2000$} & \multicolumn{2}{|c|}{$1946-1975$} & \multicolumn{2}{|c|}{$1976-2004$} \\
\hline & RF & SF & RF & SF & RF & SF \\
\hline NINO34 & -0.30 & -0.33 & -0.02 & -0.10 & -0.46 & -0.49 \\
\hline NDMI & 0.14 & 0.13 & 0.27 & 0.21 & 0.01 & 0.03 \\
\hline EQWIN & -0.07 & 0.03 & -0.12 & -0.04 & -0.25 & -0.19 \\
\hline EQWIN + NINO34 & -0.24 & -0.19 & -0.11 & -0.09 & -0.46 & -0.44 \\
\hline CEIO & -0.40 & -0.35 & -0.41 & -0.31 & -0.41 & -0.42 \\
\hline
\end{tabular}

Correlations that are significant at $99 \%, 95 \%$ and $90 \%$ corresponding to $r=0.35,0.27$ and $0.23(n=53)$ and to $r=0.45,0.35$ and 0.29 $(n=30)$ are shown in bold, bold italics and italics. 
enhanced correlation compared to that using NINO3.4 alone (Table 4).

The Indian Ocean Dipole (IOD) has a strong relationship with the September-December rainfall in Sri Lanka (Zubair et al., 2003). However, the relationship of the IOD index of Normalized Dipole Mode index (NDMI) with the Kelani rainfall and streamflow was insignificant during the Yala (Table 4).

The Yala rainfall correlates with the central equatorial Indian Ocean (CEIO) SST anomaly (Fig. 4b) at significant levels for 1975-2000 $(r>0.38)$. The CEIO index is defined as the mean SST anomaly in the region bounded by $60^{\circ} \mathrm{E}$ to $90^{\circ} \mathrm{E}$ and $10^{\circ} \mathrm{S}$ to $10^{\circ} \mathrm{N}$. Streamflow and rainfall during Yala had simultaneous correlations $(r=-0.35$ and -0.40 , respectively) with CEIO that were significant at the $95 \%$ level (Table 4). There is a relationship between ENSO and the Indian Ocean SST brought about by the Walker circulation. However, there are also independent modes of variability in the Indian Ocean. The partial correlation of the streamflow with simultaneous CEIO during Yala controlling for NINO3.4 was -0.24 and the partial correlation of NINO3.4 controlling for CEIO was -0.26 . Both of these are significant at the $90 \%$ level. Hence, it shall be useful to consider both the Pacific and Indian Ocean in developing a forecast scheme.

\section{Model prediction}

There are a variety of streamflow prediction schemes based on multiple predictors that have been previously reported on. Here, we are only presenting a proof of concept as to the viability of the ENSO based prediction scheme. We have used a principal component regression scheme (Ward and Folland, 1991) that uses the March SST in the Indo-Pacific region $\left(30^{\circ} \mathrm{S}-30^{\circ} \mathrm{N}\right.$ and $\left.30^{\circ} \mathrm{E}-60^{\circ} \mathrm{W}\right)$ to predict the Kelani River seasonal streamflow at Glencourse during
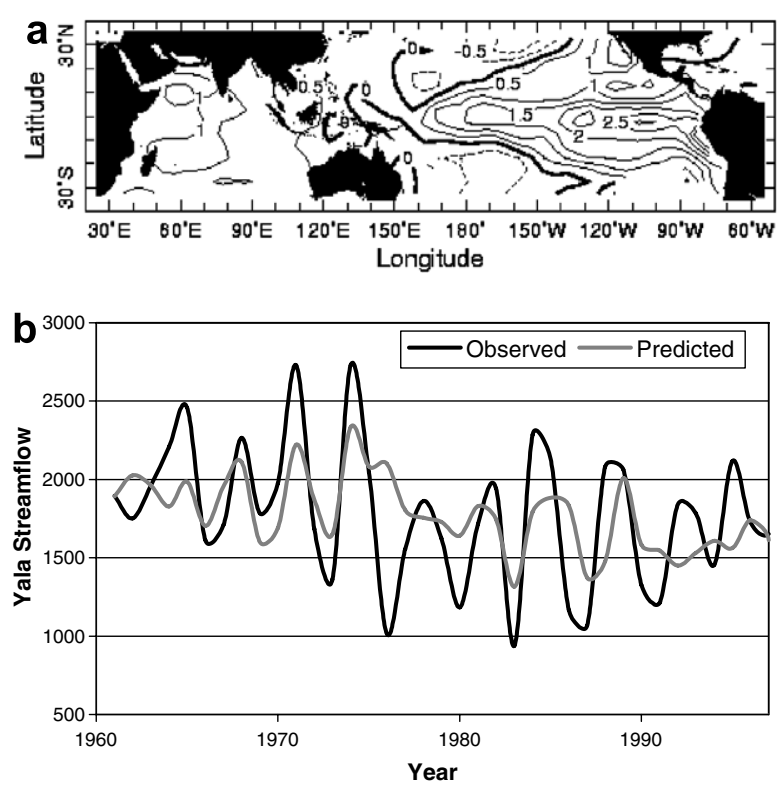

Figure 6 (a) The leading principal component of the IndoPacific SST mode during Yala from 1960 to 2000. (b) The prediction of Glencourse streamflow in cross-validated mode based on the leading principal component and the the observed Yala streamflow.
Yala from 1960 to 1997 . The predictors are chosen as the principal components of the SST's. The use of the leading mode (Fig. 6a) alone which accounts for $30 \%$ of the variance in the SST was found to give as good a prediction as using the first five principal components. The first principal component essentially contains the signature of ENSO in the Indo-Pacific region with warming in the Eastern equatorial Pacific and Central equatorial Indian Ocean. We used the period after 1960 for the cross-validated predictions as there has been a dramatic change in the streamflow and rainfall relationships with SST prior to 1950s (Zubair and Chandimala, 2006). The predictions for streamflow are shown in Fig. 6b. The Pearson correlation between the observed streamflow during Yala and the cross-validated prediction is 0.5 and the Heidke skill is 31. The predictions for the rainfall (not shown) have slightly lower skill with a Pearson correlation of 0.44 and a Heidke skill score of 35 .

The predictions of streamflow during Yala generally have the right anomaly except for seasons such as during 1976, 1980, 1986, 1991, 1993, 1995 and 1998. The principal discrepancy arises from the transition that often takes place in ENSO after the boreal spring - thus SST anomalies observed in March may differ considerably from the SST anomalies in the succeeding months. As the Yala season unfolds, it will be useful to monitor the SST conditions so that modifications to the seasonal predictions may be issued for the remainder of the season.

The prediction scheme for the early and late halves of the Maha rainfall are not presented here but based on the correlation values and skill scores, these are likely to yield predictions which are as skillful as for Yala. The correlation values for October-December rainfall with NINO3.4 ( $r=-0.44)$ is significant at the $99 \%$ level and the Heidke skill score is 18 . While the correlation value for the JanuaryMarch rainfall with NINO3.4 is not significant $(r=-0.10)$, this is due to a non-linear relationship with ENSO where rainfall in both El Nino and La Nina phases decline in relation to where there are neutral conditions. The predictability is captured by the Heidke skill score of 15 .

\section{Discussion}

The differences in saliency of ENSO relationships with streamflow and rainfall during the different seasons were brought out in this study. The correlation of ENSO indices with streamflow during Yala is greater than that with rainfall. On the other hand, the correlation between ENSO indices and rainfall during the October-December period is greater than that with streamflow. The latter disparity is due to opposing ENSO influences on rainfall in the months before and after October. Thus during a typical El Niño episode, dry anomalies from April to September are followed by wet anomalies from October to December and dry anomalies from January to March in the next year. During the typical El Niño episode, the anomalously dry April-September period leads up to an anomalously wet October-December period. Consequently, the wet rainfall anomalies during October-December are not immediately reflected in the streamflow anomalies from October to December as some of the rainfall excess is used to replenish the anomalously dry soil moisture. ENSO based rainfall predictions can be 
used along with a hydrological model or rainfall-runoff relationships to predict the October-December streamflow.

We have established relationships between SST and streamflow and rainfall that are simultaneous. To be able to predict the streamflow, lag-lead relationships are required. An alternative means of taking advantage of any simultaneous relationship is to use seasonal predictions of ENSO and SST along with the established relationships. Predictions for SST based ENSO indices are made by several forecasting centres (see http://iri.columbia.edu/climate/ ENSO/). In either case, there could be a deterioration of skill. But as shown in the case of the streamflow predictions during Yala, it is likely that useful relationships can be found even after accounting for the lag-lead relationships.

The results shown here for Yala are similar to those reported for Indian rainfall during the summer monsoon period. The lack of saliency of the equatorial Indian Oscillation in explaining the rainfall in Sri Lanka is interesting and worthy of further investigation. There are significant differences in the circulation in the boreal summer between India and Sri Lanka during this period. For example, the Tropical Convergence Zone is located over the Indian subcontinent during this period.

The predictability of both streamflow and rainfall for the Yala shall be particularly useful, as management of agriculture is sensitively dependent on in-season rainfall and streamflow. Yala is a water constrained season and thus farmers often await rains and plant crops that are of shorter duration. Updating the predictions as new ENSO and SST information becomes available during spring can lead to improved predictions for the remainder of the season.

We have presented here a proof of concept that predictions based on SST shall be useful. Further investigations of influences of other climatic precursors such as volcanic eruptions and Eurasian snow cover on streamflow and rainfall may improve the prediction scheme. Finally, given the imperfect information that is used in the prediction scheme, the imperfect understanding of the climate system and intrinsic chaotic nature of the climate system all predictions can only legitimately represented as probabilistic. This probabilistic nature should be explicitly represented to users.

\section{Conclusions}

This work has shown that there is a statistically significant influence of ENSO on Kelani streamflow and rainfall. This influence is contrasting in different seasons and shows subtle differences between rainfall and streamflow. Useful relationships were brought out by stratifying the analysis by the appropriate season. The streamflow during Yala had a consistent ENSO influence with warm phases leading to reduced flow on average. ENSO indices had correlations with streamflow during Yala $(r=-0.41$ with NINO3.4) and the rainfall during early Maha ( $r=0.44$ with NINO3.4) that were significant at the $99 \%$ level. The contingency tables of ENSO state versus flow anomalies provided further support for the predictability of streamflow during Yala. The streamflow during Yala also had a correlation $(r=-0.35)$ with the Central Equatorial Indian Ocean SST that was significant at the $95 \%$ level.
We used regression between the principal components of the March SST in the Indo-Pacific region to predict streamflow during Yala. The first principal mode which explains $30 \%$ of the SST variance was able to predict the streamflow with a correlation of 0.5 after 1960 in a cross-validated mode. The prediction scheme was prone to error in seasons in which the ENSO conditions reversed in spring such as during 1998 and thus this prediction scheme should be updated as the Yala season progresses.

The prediction of streamflow during Maha is best carried out separately for the two halves of the season. During the early Maha (October-December), rainfall had a correlation with NINO3.4 that was significant at the 95\% level. During the late Maha (January-March), streamflow and rainfall shows a $25 \%$ and a $22 \%$ drop during the El Niño phase compared to the Neutral phase. During this season, both streamflow and rainfall are diminished during the La Niña phase as well. Thus during an El Niño episode, the rainfall increases in the first half of the season and declines in the second half on average. During La Niña episodes, the rainfall declines on average throughout the season.

\section{Acknowledgements}

Valuable contributions by Upamala Tennakoon, Heli Bulathsinhala, Chanaka Wickremasinghe, Badra Nawarathna, Yoosuf Ashraj, M.R.A. Siraj, Manjula Siriwardhana, Zeenas Yahiya and P.A. Francis are gratefully acknowledged. Data were obtained from the Sri Lanka Department of Meteorology, the Department of Irrigation and the Mahaweli Authority of Sri Lanka. Discussions with Chet Ropelewski helped with the climate analysis. The comments of the anonymous reviewers helped greatly improve the substance and clarity of the paper. This paper is funded in part by a grant/cooperative agreement from the National Oceanic and Atmospheric Administration, NA050AR4311004 and a grant also from NOAA, NA03OAR4310161. The views expressed herein are those of the authors and do not necessarily reflect the views of NOAA or any of its subagencies.

\section{References}

Allen, R., Lindsey, J., Parker, D., 1996. El-Niño Southern Oscillation and Climate Variability. CSIRO Publishing, Collingwood, Vict., Australia, p. 405.

Arumugam, S., 1969. Water Resources of Ceylon its Utilization and Development. Water Resources Board publications, Colombo, Sri Lanka, p. 415.

Bamford, A.J., 1922. Ceylon Rainfall. Quarterly Journal of the Royal Meteorological Society 48, 206-207.

Chiew, F.H.S., McMahon, T.A., 2002. Global ENSO-streamflow teleconnection, streamflow forecasting and interannual variability. Hydrological Sciences Journal 47 (3), 505-522.

Chowdhury, M.R., Ward, M.N., 2004. Hydro-meteorological variability in the greater Ganges-Brahmaputra-Meghna basins. International Journal of Climatology 24 (12), 1495-1508.

Dettingter, M.D., Diaz, H.F., 2000. Global Characteristics of Stream Flow Seasonality and Variability. Journal of Hydrometeorology 1 , 289-310.

Dettinger, M.D., Cayan, D.R., McCabe, G.J., Marengo, J.A., 2000. Multiscale streamflow variability associated with El Niño/South- 
ern Oscillation. In: El Niño and the Southern OscillationMultiscale Variability and Global and Regional Impacts. Cambridge University Press, Cambridge, pp. 113-147.

Fisher, R.A., 1925. Statistical Methods for Research Workers. Oliver and Boyd, London, p. 239.

Gadgil, S., Vinayachandran, P.N., Francis, P.A., 2004. Extremes of the Indian summer monsoon rainfall, ENSO and equatorial Indian Ocean Oscillation. Geophysical Research Letters 31, L12213.

Kaplan, A., Cane, M.A., Kushnir, Y., Clement, A.C., Blumenthal, M.B., Rajagopalan, B., 1998. Analyses of global sea surface temperature: 1856-1991. Journal of Geophysical Research 103, 18567-18589.

Kiem, A.S., Franks, S.W., 2001. On the identification of ENSOinduced rainfall and runoff variability: a comparison of methods and indices. Hydrological Science Journal 46 (5), 715-727.

Kistler, R., Kalnay, E., Collins, C., Saha, S., White, G., Woollen, J., Chelliah, M., Ebisuzaki, W., Kanamitsu, M., Kousky, V., Van den Dool, H., Jenne, R., Fiorino, M., 2001. The NCEP-NCAR reanalyses: Monthly Means, CDROM and Documentation. Bulletin of the American Meteorological Society 82 (2), 247-268.

Kumar, K.K., Rajagopalan, B., Cane, M.A., 1999. On the weakening relationship between the Indian Monsoon and ENSO. Science 284, 2156-2159.

Maity, R., Nagesh Kumar, D., 2006. Bayesian dynamic modeling for monthly Indian summer monsoon rainfall using El Niño-Southern Oscillation (ENSO) and Equatorial Indian Ocean Oscillation (EQUINOO). Journal of Geophysical Research 111, D07104D07105.

Mason, S.J., Goddard, L., Graham, N.E., Yulaeva, E., Sun, L., Arkin, P.A., 1999. The IRI seasonal climate prediction system and the 1997/98 El Niño event. Bulletin of the American Meteorological Society $80,1853-1973$.

Panabokke, C.R., 1996. Soils and the Agro-Ecological Environments of Sri Lanka. Natural Resources, Energy and Science Authority of Sri Lanka, Colombo, p. 220.

Puvaneswaran, K.M., Smithson, D.A., 1993. Controls on the precipitation distribution in Sri Lanka. Theoretical and Applied Climatology 47, 105-115.

Rasmusson, E.M., Carpenter, T.H., 1983. The relationship between Eastern equatorial Pacific sea temperature and rainfall over India and Sri Lanka. Monthly Weather Review 115, 1606-1626.

Ropelewski, C.F., Jones, P.D., 1987. An extension of the TahitiDarwin Southern Oscillation Index. Monthly Weather Review 115 2161-2165.
Ropelewski, C.F., Halpert, M.S., 1987. Global and regional scale precipitation pattern associated with El Niño/Southern Oscillation. Monthly Weather Review 115, 1606-1626.

Shrestha, A., Kostaschuk, R., 2005. El Niño/Southern Oscillation (ENSO)-related variability in mean-monthly streamflow in Nepal. Journal of Hydrology 308 (1-4), 33-49.

Siyambalapitiya, T., Samarasinghe, A.K., 1993. Power generation in Sri Lanka: status and future options. Power Engineering Journal 7 (1), 19-36.

Suppiah, R., 1996. Spatial and temporal variations in the relationships between the Southern Oscillation phenomenon and the rainfall of Sri Lanka. International Journal of Climatology 16, 1391-1407.

Suppiah, R., 1997. Extremes of the Southern Oscillation phenomenon and the rainfall of Sri Lanka. International Journal of Climatology 17, 87-101.

Trenberth, K.E., 1997. The definition of El Niño. Bulletin of the American Meteorological Society 78 (12), 2771-2777.

Ward, M.N., Folland, C.K., 1991. Prediction of seasonal rainfall in the north Nordeste of Brazil using eigenvectors of the seasurface temperatures. International Journal of Climatology 11, 711-743.

Whitaker, D.W., Wasimi, S.A., Islam, S., 2001. The El Niño Southern Oscillation and long-range forecasting of the flows in the Ganges. International Journal of Climatology 21 (1), 77-87.

Wilks, D.S., 1995. Statistical methods in Atmospheric sciences. Academic press, San Diego, CA, p. 467.

Zubair, L., 2002. El-Niño-Southern Oscillation influences on rice production in Sri Lanka. International Journal of Climatology 22, 242-250.

Zubair, L., 2003b. ENSO influences on Mahaweli Streamflow in Sri Lanka. International Journal of Climatology 23 (1), 91-102.

Zubair, L., 2003c. Sensitivity of Kelani streamflow in Sri Lanka to ENSO. Hydrological Processes 17 (12), 2439-2448.

Zubair, L., 2004. Weather and climate of Sri Lanka and impacts and adaptation: A reference guide. Natural Resources Management Services, Sri Lanka, Kandy, ISBN 955-8968-00-5, p. 116.

Zubair, L., Ropelewski, C.F., 2006. The strengthening relationship of ENSO and the North-East Monsoon rainfall over Sri Lanka and Southern India. Journal of Climate 19 (8), 1567-1575.

Zubair, L., Chandimala, J., 2006. Epochal Changes in ENSOstreamflow relations in Sri Lanka. Journal of Hydrometeorology 7 (6), 1237-1246.

Zubair, L., Rao, S.C., Yamagata, T., 2003a. Modulation of Sri Lanka Rainfall by the Indian Ocean Dipole. Geophysical Research Letters 10 (2), 1063-1066. 